\title{
Implementasi Penanggulangan Narkoba dalam Islam melalui Partisipasi Pemandu Wisata Lokal di Kawasan Wisata Kota Tua Jakarta
}

\author{
Heryanti Utami \\ Universitas Negeri Jakarta \\ heryanti-utami@unj.ac.id \\ Sari Narulita \\ Universitas Negeri Jakarta \\ Sari-Narulita@unj.ac.d
}

\begin{abstract}
The purpose of this study is to determine the extent to which the Local Tourism Guide Participation in Overcoming Drug Abuse in the Jakarta Old Town and Improving the image of Jakarta Old Town in particular and Jakarta in general as a tourist destination far from drugs. In Islam, the prohibition of drugs analogous to alcoholic liquor that can damage the mind, memory, heart, soul, mental and physical health. Even the legal content of prohibited drugs exceeds the extent of alcoholic beverages because of its highly destructive addictive properties. Therefore it needs to be handled very seriously in various aspects. The findings illustrate that drug abuse also occurs due to outside influences that come to the area by carrying drugs such as tourists or people outside the Jakarta Old Town, for that tour guides should include the danger of the drug cases when they guide.
\end{abstract}

Keywords: Drug Abuse, Participation

\begin{abstract}
Abstrak
Tujuan penelitian ini adalah Mengetahui sejauh mana Partisipasi Pemandu Wisata Lokal dalam Menanggulangi Penyalahgunaan Narkoba di Kawasan Wisata Kota Tua Jakarta dan Memperbaiki citra Kota Tua Jakarta pada khususnya dan Jakarta pada umumnya sebagai destinasi wisata yang jauh dari narkoba. Dalam Islam, keharaman narkoba diqiyaskan atau dianalogikan dengan keharaman minuman keras yang dapat merusak akal pikiran, ingatan, hati, jiwa, mental dan kesehatan fisik. Bahkan kadar hukum keharaman narkoba melebihi kadar keharaman minuman keras karena sifat adiktifnya yang sangat merusak. Karenanya perlu penanggulangan dengan sangat serius di berbagai aspeknya. Hasil temuan menggambarkan bahwa penyalahgunaan narkoba juga terjadi akibat adanya pengaruh luar yang datang ke kawasan tersebut dengan membawa narkoba seperti para wisatawan atau masyarakat luar Kota Tua Jakarta, untuk itu para pemandu wisata memasukkan materi narkoba ini ke dalam materi pemanduan ketika mereka memandu.
\end{abstract}

Kata Kunci: Penanggulangan Narkoba, Partisipasi 


\section{A. Pendahuluan}

Saat ini, sektor pariwisata merupakan sektor andalan pemerintah untuk meningkatkan devisa negara. Pariwisata merupakan salah satu gerbang untuk meningkatkan pendapatan di suatu daerah, sehingga setiap kawasan dan daerah di Indonesia mulai berlomba untuk meningkatkan kualitas pariwisatanya. Namun, seiring dengan pertumbuhan pariwisata tersebut maka muncullah masalah lainnya dimana sektor kepariwisataan sangat rentan terhadap berbagai fenomena seperti eksploitasi seksual, HIV dan AIDS, penyelundupan dan penyebaran narkoba..

Narkoba atau kadang dikenal dengan NAPZA merupakan bahan/zat terlarang yang apabila masuk ke dalam tubuh akan mempengaruhi tubuh terutama susunan syaraf pusat/otak sehingga bilamana disalahgunakan akan menyebabkan gangguan fisik, psikis/jiwa dan fungsi sosial ${ }^{1}$. Dikatakan pula Narkotika dan Obat-obatan terlarang (NARKOBA) atau Narkotik, Psikotropika, dan Zat Aditif (NAPZA) adalah bahan / zat yang dapat mempengaruhi kondisi kejiwaan / psikologi seseorang (pikiran, perasaan dan perilaku) serta dapat menimbulkan ketergantungan fisik dan psikologi. ${ }^{2}$

Narkotika adalah zat atau obat yang berasal dari tanaman atau bukan tanaman baik sintetis maupun semisintetis yang akan menyebabkan perubahan kesadaran, mengurangi sampai menghilangkan rasa sakit dan dapat menimbulkan ketergantungan (adiksi). Jenis Narkotika yang sering disalahgunakan adalah morfin, heroin (putauw), petidin, termasuk ganja atau kanabis, mariyuana, hashis dan kokain. Adapun yang dimaksud dengan golongan Psikotropika adalah zat atau obat baik alami maupun sintetis namun bukan Narkotika yang berkhasiat aktif terhadap kejiwaan (psikoaktif) melalui pengaruhnya pada susunan syaraf pusat sehingga menimbulkan perubahaan tertentu pada aktivitas mental dan perilaku. $^{3}$

Pemerintah telah memberlakukan Undang-Undang untuk penyalahgunaan narkoba yaitu UU No.5 tahun 1997 tentang Psikotropika dan UU No.22 tahun 1997 tentang Narkotika. Narkotika menurut UU RI No 22 / 1997, Narkotika, yaitu zat atau obat yang berasal dari tanaman atau bukan tanaman baik sintetis maupun semisintetis yang dapat

\footnotetext{
1. Buku panduan BNN, Pelajar dan Bahaya Narkotika, Deputi Bidang Pencegahan Direktorat Diserminasi Informasi, Jakarta 2010

2. http://dedihumas.bnn.go.id/read/section/artikel/2014/03/10/929/pengertian-narkoba, diakses pada tanggal 10 Maret 2017, pukul 09.00 wib

3. Buku Advokasi Pencegahan Penyalahgunaan Narkoba, BNN : 2009
} 
menyebabkan penurunan atau perubahan kesadaran, hilangnya rasa, mengurangi sampai menghilangkan rasa nyeri, dan dapat menimbulkan ketergantungan. ${ }^{4}$

Dalam agama, khususnya Islam, keharaman narkoba diqiyaskan atau dianalogikan dengan keharaman minuman keras yang dapat merusak akal pikiran, ingatan, hati, jiwa, mental dan kesehatan fisik. Bahkan kadar hukum keharaman narkoba melebihi kadar keharaman minuman keras karena sifat adiktifnya yang sangat merusak. Keharaman atasnya tampak dalam QS Al-Baqarah: 195, QS An-Nisa': 29, QS Al-Maidah: 90, 91 dan QS. Al-Baqarah: 219. Juga didukung oleh beberapa narasi hadits yang diriwayatkan oleh para perawi hadits yang tsiqqah yakni terpercaya, seperti yang diriwayatkan oleh Bukhari dan Muslim bahwa rasulullah saw. Menyatakan bahwa "Tiap-tiap barang yang memabukkan adalah haram"

Beberapa faktor penyebab penyalahgunaan narkoba sebenarnya banyak sekali. Sebagian dipengaruhi oleh masalah sosial, fisik dan psikis. Faktor yang mendorong, diantaranya, 1) Pengendalian diri yang lemah, 2) Kondisi kehidupan keluarga, 3) Temperamen sulit, 4) Mengalami gangguan perilaku, 5) Suka menyendiri dan berontak, 6) Prestasi sekolah yang rendah, 7) Tidak di terima di kelompok, 8) Berteman dengan pemakai

Penyalahgunaan narkoba sebenarnya dapat terjadi akibat adanya tekanan secara psikologis; diantaranya adalah karena Faktor Pribadi. Faktor ini sebenarnya dapat dimulai pada saat remaja, dimana pada remaja sedang mengalami perubahan biologis, psikologi maupun sosial yang pesat. Adanya perasaan rendah diri, emosi yang belum stabil, tidak dapatnya menyelesaikan masalah kehidupan dan sebagainya menjadikan seseorang beresiko lebih besar menggunakan Narkoba.

Namun tak jarang, faktor lingkungan pun menjadi salah satu penyebabnya. Faktor lingkungan meliputi faktor keluarga dan lingkungan pergaulan kurang baik sekitar rumah, sekolah, teman sebaya, maupun masyarakat, seperti komunikasi orang tua dan anak kurang baik, orang tua yang bercerai, kawin lagi, orang tua terlampau sibuk, acuh, orang tua otoriter dan sebagainya. Hal tersebut membuat seseorang menjadi lemah mental yang mengakibatkan mudahnya seseorang dipengaruhi untuk menggunakan narkoba; dan yang terakhir adalah faktor ketersediaan narkoba. Penggunaan narkoba sendiri terjadi karena mudahnya mendapatkan akses untuk mengkonsumsi narkoba, seperti akses yang mudah

${ }^{4}$. http://hariannetral.com/2014/10/pengertian-narkoba-bahaya-dan-dampak-narkoba.html diakses pada tanggal 10 Maret 2017, pukul 09.00 wib 
melalui internet, toko-toko obat ilegal, dan salah satunya di lokasi pariwisata. ${ }^{5}$ Selain itu hal lain yang tak kalah penting adalah lemahnya hukuman bagi pengedar narkoba, yang membuat Indonesia menjadi sasaran peredaran narkoba skala besar.

Sektor pariwisata cenderung menjadi salah satu tempat yang mudah untuk melakukan peredaran narkoba, kemunculan ESA, HIV maupun Aids, seringkali dijadikan akses yang sangat mudah bagi praktek-praktek tersebut sehingga bermunculanlah dampak negatif pariwisata. ${ }^{6}$

Salah satu hal yang paling terlihat dampaknya adalah penggunaan narkoba. Penggunaan narkoba ini tidak hanya oleh para wisatawan saja, namun banyak sekali warga sekitar daerah tujuan wisata yang turut mengkonsumsi narkoba. Daerah rawan narkoba dan juga objek wisata favorit yang rawan peredaran narkoba salah satunya dalah Kawasan Kota Tua Jakarta. Terbukti dengan banyaknya masyarakat yang terjaring razia narkoba yang dilakukan oleh pemerintah dalam hal ini BNN (Badan Narkotika Nasional) di kawasan objek wisata tersebut. ${ }^{7}$

Kota tua adalah sebuah kawasan kota yang sebelumnya dibangun oleh pemerintahan Belanda sebagai pusat perdagangan di Asia. Karena letaknya berada di tengah kepulauan Indonesia, akhirnya menjadikan Batavia (Jakarta) sebagai pusat perdagangan dari dan keluar negeri menggunakan pelayaran.

Di Jakarta, kawasan kota tua ini merupakan salah satu area yang masih hingga saat ini terjaga dan dikembangkan menjadi objek wisata sejarah oleh pemerintah. Kota Tua ini berisikan bangunan-bangunan tua yang memiliki sejarah dan beberapa diantaranya masih berfungsi dengan baik, seperti Stasiun Jakarta Kota \& Kantor Pos Indonesia, beberapa diantaranya sudah dijadikan museum untuk mengenang sejarah di kala itu. Adapun museum terkenal yang bisa dikunjungi yaitu Museum Bank Indonesia, Museum Wayang, Bekas Kantor Gubernur, Museum Keramik dan beberapa bangunan tua disana.

Kota Tua ini memiliki aktivitas yang cukup menarik dan dapat dipandu oleh para pemandu wisata lokal disekitarnya. Para pemandu wisata tersebut berasal dari daerah sekitar Kota Tua dan daerah-daerah lainnya. Mereka bekerja mendampingi wisatawan lokal dan mancanegara selama berada di Kawasan Kota Tua Jakarta. Hampir sepanjang

\footnotetext{
${ }^{5}$.https://agus34drajat.files.wordpress.com/2010/10/buku-pedoman-praktis-mengenai-penyalahgunaannapza-bagi-petugas.pdf. Diakses pada tanggal 31 Juli 2017 pukul 15.30 wib

6 . http://www.pikiran-rakyat.com/bandung-raya/2011/07/07/151095/sektor-kepariwisataan-rentanterhadap-fenomena-narkoba) diakses pada tanggal 10 Maret 2017, pukul 09.00 wib

7. Lihat http://news.liputan6.com/read/761474/razia-di-kawasan-kota-tua-14-pengunjung-positifnarkoba diakses pada tanggal 10 Maret 2017, pukul 09.00 wib; http://news.liputan6.com/read/2445712/bnnmusnahkan-120-kg-sabu-di-kota-tua. Diakses pada tanggal 31 Juli 2017 pukul 15.30 wib
} 
hari mereka berada di kawasan dan terlibat secara langsung oleh komunitas, pemerintah, warga dan wisatawan, sehingga mereka benar-benar menguasai kondisi kawasan tersebut. ${ }^{8}$

Dalam penelitian ini, penulis mencoba mengkaji Implementasi Penanggulanagn Narkoba dalam Islam melalui partisipasi pemandu wisata lokal, sebagai komunitas yang paling sering berada di kawan Kota Tua Jakarta untuk bersama-sama terlibat dalam penanggulangan penyalahgunaan narkoba di kawasan tersebut.

Dengan demikian, dipahami bahwa tujuan penelitian ini adalah Mengetahui sejauh mana Partisipasi Pemandu Wisata Lokal dalam Menanggulangi Penyalahgunaan Narkoba di Kawasan Wisata Kota Tua Jakarta dan Memperbaiki citra Kota Tua Jakarta pada khususnya dan Jakarta pada umumnya sebagai destinasi wisata yang jauh dari narkoba

\section{B. Metodologi Penelitian}

Pendekatan penelitian yang digunakan dalam penelitian ini adalah pendekatan penelitian kualitatif deskriptif dengan mendeskripsikan berbagai fenomena yang terangkum dalam rumusan permasalahan penelitian ini. Data dalam penelitian ini diperoleh dengan metode observasi, wawancara, dan studi dokumen. Data yang diperoleh dianalisa dengan teknik analisis deskriptif kualitatif. Selanjutnya, hasil analisis data disajikan secara secara formal, yaitu dalam bentuk bagan, grafik, dokumen, gambar, dan sebagainya, dan secara informal yaitu dalam bentuk narasi.

Data yang diperoleh dengan teknik observasi, wawancara dan studi dokumen dalam penelitian ini selanjutnya dianalisa dengan teknik analisis deskriptif kualitatif. Menurut Moleong, analisis data adalah proses mengorganisir dan mengurutkan data ke dalam pola, kategori, dan satuan uraian dasar sehingga dapat ditemukan tema untuk dirumuskan menjadi kesimpulan". Selanjutnya, Bogdan dan Biklen dalam Moleong menjelaskan analsisis data kualitatif adalah upaya yang dilakukan dengan jalan bekerja dengan data, mengorganisasikan data, memilah-milahnya menjadi satuan yang dapat dikelola, mensintesiskannya, mencari dan menemukan pola, menemukan apa yang penting dan apa yang dipelajari, dan memutuskan apa yang dapat diceritakan kepada orang lain ${ }^{10}$.

Adapun proses analisis data dengan teknik analisis deskriptif kualitatif dalam penelitian ini adalah sebagai berikut:

\footnotetext{
${ }^{8}$ http://megapolitan.kompas.com/read/2016/06/23/11491421/presiden.jokowi.akan.hadiri.peringatan.h ari.anti-narkotika.di.kota.tua. Diakses pada tanggal 31 Juli 2017 pukul 15.30 wib; http://hukum.rmol.co/read/2016/06/26/251298/Capaian-Komjen-Buwas-Di-Hari-Anti-Narkoba-2016Diakses pada tanggal 31 Juli 2017 pukul $15.30 \mathrm{wib}$

${ }^{9}$ Moleong, Lexy J. 2012. Metodologi Penelitian Kualitatif. Bandung : Remaja Rosdakarya

${ }^{10}$ Moleong, Lexy J. 2012. Metodologi Penelitian Kualitatif. Bandung : Remaja Rosdakarya
} 
1. Reduksi data

Sugiyono mengatakan bahwa mereduksi data berarti merangkum, memilih hal-hal yang pokok, memfokuskan pada hal-hal yang penting, dicari tema dan polanya, dan membuang yang tidak perlu ${ }^{11}$.

2. Penyajian data

Penyajian data dimasudkan agar lebih mempermudah bagi peneliti untuk dapat melihat gambaran secara keseluruhan atau bagian-bagian tertentu dari data penelitian. Miles dan Huberman dalam Sugiyono menjelaskan bahwa yang paling sering digunakan untuk menyajikan data dalam penelitian kualitataif adalah dengan teks yang bersifat naratif ${ }^{12}$.

Penelitian ini menggunakan metode penelitian kualitatif dengan melakukan obeservasi lapangan dan wawancara. Rancangan penelitian ini disajikan dalam Gambar sebagai berikut:

\section{Rancangan Penelitian}

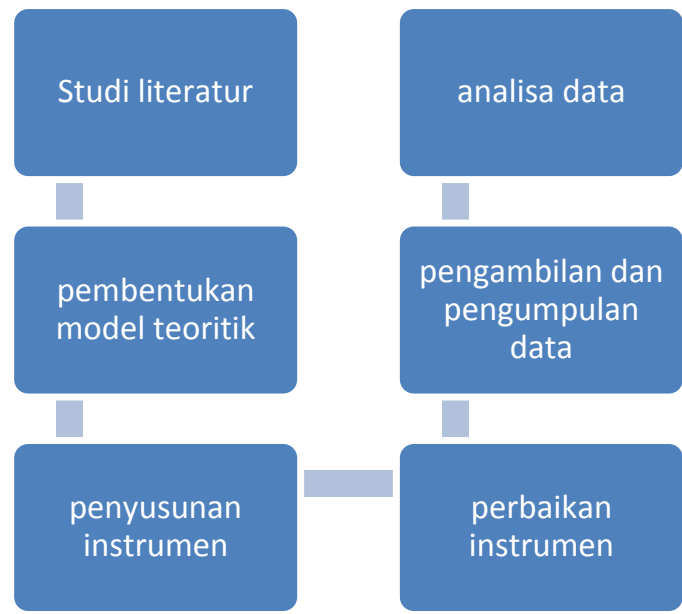

Sumber : Data Olahan Penulis, 2017

Penelitian ini terdiri dari 6 urutan, yaitu studi literatur, kemudian pembentukan model teoretik, penyusunan instrument (daftar wawancara), perbaikan instrumen, pengambilan dan pengumpulan data dan analisa data.

Penelitian ini berlokasi di Kawasan Kota Tua Jakarta. Kegiatan ini dibuat selama 4 (empat) bulan, dengan pembagian jadwal waktu yang selalu dievaluasi setiap 1 (bulan) sekali. Hal ini dilakukan agar penyimpangan dalam pelaksanaan dapat segera dilakukan pengendalian dengan Informan kunci dalam penelitian ini adalah Pemandu Wisata Lokal

\footnotetext{
${ }^{11}$ Sugiyono.2012. Memahami Penelilitian Kualitatif. Bandung : AlfaBeta

${ }^{12}$ Sugiyono.2012. Memahami Penelilitian Kualitatif. Bandung : AlfaBeta
} 
Kota Tua Jakarta. Pemandu wisata lokal dibawah naungan Jakarta Good Guide. Jumlah informan kunci yang diambil adalah 10 pemandu lokal Kota Tua yang telah berpengalaman.

Penelitian ini menggunakan pedoman wawancara kepada 10 orang pemandu wisata lokal dibawah koordinasi Jakarta Good Guide sebagai sumber pemandu wisata lokal resmi di Kota Tua Jakarta untuk memperoleh data. Penelitian ini juga menggunakan pedoman observasi yang dilakukan oleh peneliti langsung kepada beberapa pemandu wisata untuk mengamati partisipasi para pemandu wisata lokal resmi di Kota Tua Jakarta dalam memberantas narkoba dikalangan turis asing dan lokal selama berada di dalam bis dan tempat wisata (Kota Tua)

\section{Hasil dan Pembahasan}

Partisipasi adalah upaya dan peran serta masyarakat dalam mengikuti kegiatan. Partisipasi memiliki makna perihal turut berperan serta dalam suatu kegiatan; keikutsertaan; peran serta. Partisipasi dapat didefinisikan sebagai keterlibatan mental/pikiran dan emosi/perasaan seseorang di dalam situasi kelompok yang mendorongnya untuk memberikan sumbangan kepada kelompok dalam usaha mencapai tujuan serta turut bertanggung jawab terhadap usaha yang bersangkutan. ${ }^{13}$

Partisipasi masyarakat adalah keterlibatan masyarakat sesuai dengan hak dan kewajibannya sebagai subyek dan obyek pembangunan. Keterlibatan dalam tahap pembangunan ini dimulai sejak tahap perencanaan sampai dengan pengawasan berikut segala hak dan tanggung jawabnya. Menurut Ericson bentuk partisipasi masyarakat dalam pembangunan terbagi atas 3 tahap, yaitu, 1) Partisipasi di dalam tahap perencanaan (idea planing stage $)^{14}$. Partisipasi pada tahap ini maksudnya adalah pelibatan seseorang pada tahap penyusunan rencana dan strategi dalam penyusunan kepanitian dan anggaran pada suatu kegiatan/proyek. Masyarakat berpartisipasi dengan memberikan usulan, saran dan kritik melalui pertemuan-pertemuan yang diadakan; 2) Partisipasi di dalam tahap pelaksanaan (implementation stage). Partisipasi pada tahap ini maksudnya adalah pelibatan seseorang pada tahap pelaksanaan pekerjaan suatu proyek. Masyarakat disini dapat memberikan tenaga, uang ataupun material/barang serta ide-ide sebagai salah satu wujud partisipasinya pada pekerjaan tersebut; 3) Partisipasi di dalam pemanfaatan (utilitazion stage). Partisipasi pada tahap ini maksudnya adalah pelibatan seseorang pada tahap

\footnotetext{
${ }^{13}$ http://kbbi.web.id/partisipasi diakses pada tanggal 27 Februari 2017, pukul 06.53 wib

${ }^{14}$ Slamet, 1994, Pembangunan Masyarakat Berwawasan Partisipasi, Surakarta : UNS Press, h. 89
} 
pemanfaatan suatu proyek setelah proyek tersebut selesai dikerjakan. Partisipasi masyarakat pada tahap ini berupa tenaga dan uang untuk mengoperasikan dan memelihara proyek yang telah dibangun.

Menurut Conyers, ada tiga alasan utama mengapa partisipasi masyarakat mempunyai sifat sangat penting ${ }^{15}$. Pertama, partisipasi masyarakat merupakan suatu alat guna memperoleh informasi mengenai kondisi, kebutuhan dan sikap masyarakat setempat, yang tanpa kehadirannya program pembangunan serta proyek-proyek akan gagal. Kedua, masyarakat akan lebih mempercayai proyek atau program pembangunan jika merasa dilibatkan dalam proses persiapan dan perencanaannya, karena mereka akan lebih mengetahui seluk beluk proyek tersebut dan akan mempunyai rasa memiliki terhadap proyek tersebut. Ketiga, timbul anggapan bahwa merupakan suatu hak demokrasi bila masyarakat dilibatkan dalam pembangunan masyarakat mereka sendiri. Dapat dirasakan bahwa merekapun mempunyai hak untuk turut memberikan saran dalam menentukan jenis pembangunan yang akan dilaksanakan.

Sedangkan yang dimaksud dengan Pemandu Wisata atau pramuwisata adalah seseorang yang bertugas memberikan bimbingan, penjelasan dan petunjuk tentang obyek wisata serta membantu keperluan wisatawan lainnya. Pramuwisata sering disebut sebagai ujung tombak kepariwisataan dan pasukan elit dibidang kepariwisataan. Pramuwisata diberi julukan; “ The Ambassador of The Country” (Duta Besar dalam Scoup Kecil).

Kawasan Kota Tua sebagai cikal bakal kota Jakarta dibangun oleh Fatahillah, 22 Juni 1527, setelah sebelumnya berupa Kota Sunda Kelapa dengan Pelabuhan Sunda Kelapa yang didirikan oleh Kerajaan Sunda Pajajaran di awal abad ke-14. Kawasan yang diganti namanya menjadi Jayakarta oleh Fatahillah, berkembang menjadi kota pelabuhan internasional di mana berbagai bangsa tinggal sehingga terbentuklah suatu budaya campuran.

Setelah ditaklukan olah Belanda pada tahun 1619, di atas puing kota dibangunlah Batavia yang struktur kotanya mirip dengan Amsterdam. Kota ini dikelilingi oleh benteng pertahanan untuk menghadapi serangan musuh, dan permukimannya berpola grid yang dipisahkan dengan kanal dan jalan. Kali Ciliwung yang lebih dikenal dengan Kali Besar membagi kota menjadi dua sisi, di mana Kali Besar ini sekaligus merupakan kawasan pusat perputaran ekonomi.

${ }^{15}$.Conyers, Perencanaan Sosial di Dunia Ketiga, Suatu Pengantar, Yogyakarta : Gajah Mada University Press, 1994, h. 154 
Menyandang julukan "Queen of the East", area pusat perputaran ekonomi sekaligus pusat pemerintahan sejak jaman kekuasaan Pangeran Jayakarta, Portugis, Belanda, dan Cina ini sangat ramai dikunjungi berbagai pelaut dan pedagang asing untuk mendapatkan rempah-rempah. Hal ini memicu perkembangan kota tua pada berbagai aspeknya, seperti luas wilayah, pemerintahan, sosial politik, penduduk dan seni budaya.

Berdasarkan kajian sejarah, sebagian besar dari Kawasan Sunda Kelapa (zona 1) dan Zona 2 Kawasan Cagar Budaya Kota Tua adalah cikal bakal Kota Tua, yaitu kota yang pada masa kolonial berada didalam dinding benteng, yang ditinggali oleh Bangsa Belanda. Kawasan ini dahulu dibatasi oleh Sungai Ciliwung di Sebelah Timur, Kanal Stadt Buiten Gracht Sebelah Barat (kini Sungai Krukut), Kanal Stadt Buiten Gracht Sebelah Selatan (kini Jalan Jembatan Batu dan Jalan Asemka), dan Laut di Utara (termasuk Pelabuhan Sunda Kelapa). Di luar kawasan ini terdapat permukiman - permukiman lain yang bersama - sama kota di dalam benteng yang merupakan Kawasan Cagar Budaya Kota Tua seperti yang tercakup pada Peraturan Gubernur Provinsi DKI Jakarta No. 34 Tahun 2005.

Luas Kawasan Kota Tua Jakarta adalah 846 ha. Kawasan ini terletak diantara 2 kotamadya, yaitu Kotamadya Jakarta Utara dan Kotamadya Jakarta Barat. Secara administratif, Kawasan Kota Tua Jakarta memiliki batas Bagian Utara adalah Jalan Pakin, Jalan Lodan; Bagian Barat adalah Jalan Gedong Panjang, Jalan KH Moh. Mansyur; Bagian Selatan adalah Jalan Mangga Besar; sedang bagian Timur adalah Jalan Gunung Sahari. Untuk lebih jelasnya dapat dilihat pada peta zonasi kawasan Kota Tua Jakarta yang terdapat pada halaman berikut:

\section{Peta Batasan Kawasan Penelitian (Zona 2)}

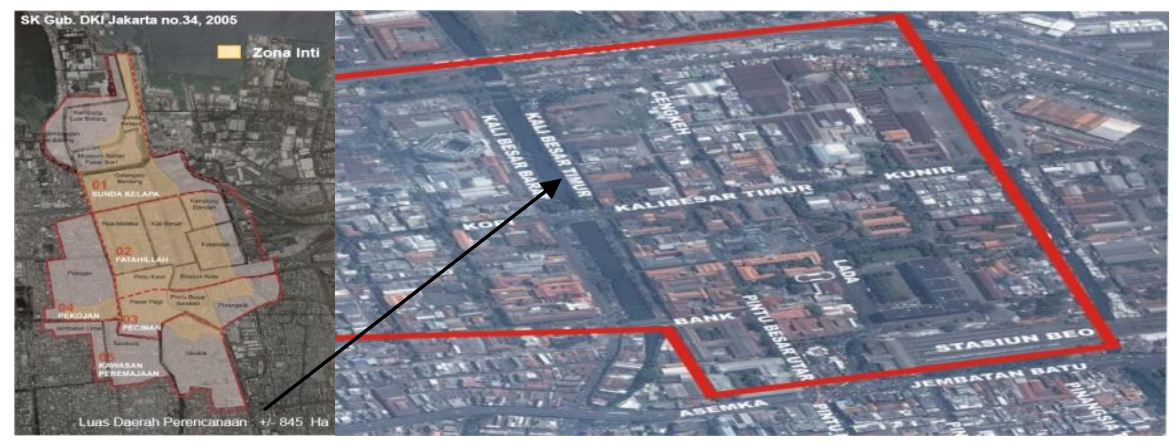

Sumber : Data Olahan Penulis, 2009

Kota Tua Jakarta memiliki daya tarik dan potensi yang luar biasa. Selain bangunanbangunan tua peninggalan kolonialisasi Balanda, Kota Tua juga memiliki beberapa museum dan daya tarik pendukung yang diminati pengunjung. Berikut ini adalah peta daya tarik Kota Tua Jakarta zona 2 


\section{Peta Daya Tarik Kota Tua Jakarta Zona 2}

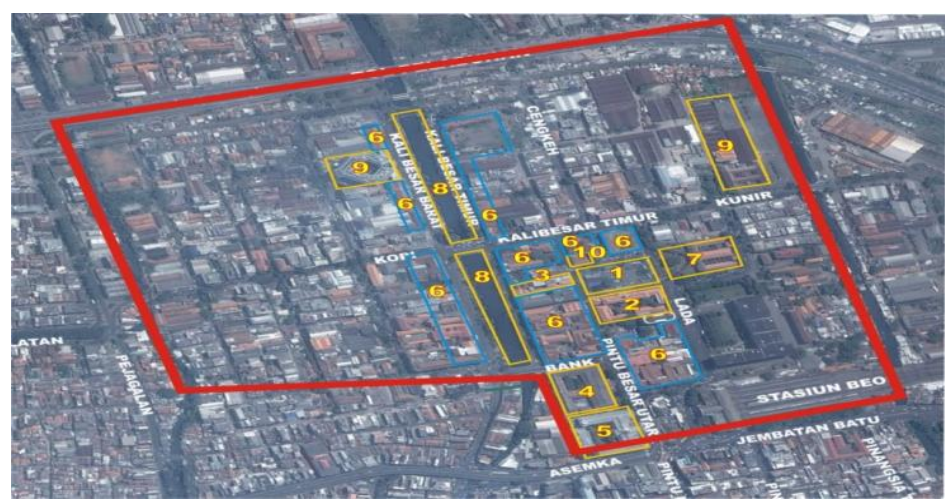

Sumber : Data Olahan Penulis, 2009

Keterangan:

1. Taman Fatahillah

2. Museum Sejarah Jakarta

3. Museum Wayang

4. Museum Bank Indonesia

5. Museum Bank Mandiri

6. Bangunan-bangunan Tua

7. Museum Seni Rupa dan Keramik

8. Kali Besar

9. Akomodasi

10. Sarana Makan Minum

Jakarta Good Guide merupakan sebuah wadah yang memiliki kegiatan pemanduan wisata di Jakarta, terutama di Kota Tua Jakarta. Berdiri sejak September 2014 dan diprakarsai oleh Farid dan Chanda. Pertama kali mereka mengadakan kegiatan city tour di Jakarta dan kemudian mulai melakukan kegiatan walking tour di Jakarta.

Jakarta Good Guide ini memiliki kantor di Gedung Olveh Lt.3 Jl. Jembatan Batru No. 50, Pinangsia, Tamansari, Jakarta Barat. Dalam kegiatannya, Jakarta Good Guide telah menyelenggarakan perjalanan ke berbagai tempat di Jakarta, yaitu :

\section{City Center 1 :}

1. Monas

2. Museum Nasional

3. Mahkamah Konstitusi

4. Istana Presiden

5. Mesjid Istiqlal
6. Katedral Jakarta

\section{City Center 2 :}

1. Lapangan Banteng

2. Hotel Borobudur

3. Gedung Pancasila

4. Gereja Immanuel 
5. Galeri Nasional

6. Kedutaan Vatikan

7. Rumah PLN

8. Patung Pahlawan

9. Kedutaan USA

Kota Tua :

1. Museum Bank Indonesia

2. Sungai Besar

3. Toko Merah

4. Jembatan

5. Pelabuhan Sunda Kelapa

6. Lapangan Fatahillah

Kota Cina:

1. Candra Naya

2. Petak Semnbilan

3. Dharma Bakti

4. Gereja Santa Maria de Fatima

5. Toa se Bio

6. Gloria Food street

\section{Menteng:}

1. Taman Suropati

2. Museum Kebangkitan Nasional

3. Sekolah Obama

4. Museum Nasional

5. Kunstkring Art Gallery

6. Mesjid Cut Mutia
Pasar Baru :

1. Stasiun Juanda

2. Gedung Filateli

3. Gedung Seni

4. Lapangan Banteng

5. Kementerian Keuangan

6. Gedung Antara

7. Pasar Baru

8. Gereja PNIEL

\section{Cikini :}

1. Gedung Joeang 45

2. Taman Ismail Marzuki

3. SMPN 1 Jakarta

4. Perguruan Cikini

5. Pasar Antik jl. Surabaya

Jatinegara :

1. Stasiun Jati Negara

2. Pasar Rawa Bening

3. Gedung Ex kodim

4. Shia Djin Kong

5. Masjid Al Anwar

6. Pasar Barang Bekas

7. Gereja St. Maria de Fatima

8. Kampung Pulo

9. Wihara Amurva Bhumi

10. GerejaKoinonI

Adapun struktur organisasi Jakarta Good Guide adalah sebagai berikut :
a) Founder / Ketua : Farid Mardhiyanto
b) Co-Founder / Wakil Ketua : Candha Adwitiyo
c) Div. Walking Tour : Farid Mardhiyanto
d) Div. Private Tour : Candha Adwitiyo
e) Div. Guide Development : Indra Diwangkara
f) Div. Procurement : Huans Sholehan
g) Div. Financial : Rosalina Rita 
h) Div. Marketing : Lelly Faizah

Didukung Pemandu Wisata Utama yakni 1) Farid Mardhiyanto, 2) Candha Adwitiyo, 3) Indra Diwangkara, 4) Huans Sholehan, 5) Lelly Faizah; serta Pemandu Wisata tambahan, 1) Cindy, 2) Mochi, 3) Mita. Secara resmi Jakarta Good Guide hanya memiliki 8 (delapan) pemandu resmi tetap, sisanya adalah tenaga pemandu free lance yang bekerja apabila mereka memerlukan tambahan pemandu wisata.

Kaitannya dengan penanggulangan narkoba dalam Islam, pada dasarnya ada kesamaan tujuan yang ingin dicapai antara BNN dan ajaran yang diajarkan oleh Islam dan agama lainnya yakni mencegah perbuatan jahat lebih diutamakan sebelum upaya untuk mendapatkan kemaslahatan, sebagaiman ditulis daalam kaidah usul fikih "dar; ul mafasid muqoddam 'ala jalbil mashalih" oleh karena itu maslah narkoba dalam Islam melihat pada dua sisi yakni pengguna dan penjuakl narkoba, bagi pengguna yang utama adalah melakukan tindakan preventif, persuasif dan rehabilitative, sedangkan bagi para pengedar, penyelundup dan produsen narkoba adalah sesuai Fatwa Majlis Ulama Indonesia, yang ditetapkan pada tanggal 12 Desember 2014 melalui rapat pleno Komisi Fatwa, yang berisikan menjatuhkan hukuman ta'zir sampai hukuman mati kepada produsen, bandar, dan pengedar narkoba sesuai dengan kadar narkoba yang dimiliki atau diproduksi atau telah beberapa kali terbukti menyalahgunakan narkoba demi kepentingan kemashalatan yang lebih besar. (Kiblat berita visi dan investigasi)

\section{Wawasan mengenai Narkoba di Kalangan Pemandu Wisata Lokal Kota Tua}

\section{Jakarta}

Maraknya penggunaan narkoba di Kawasan Kota Tua sebenarnya sudah berlangsung sejak lama. Melalui wawancara yang dilakukan peneliti kepada para pemandu wisata lokal tersebut menunjukkan bahwa sebenarnya mereka sedikit banyak telah mengetahui adanya penggunaan dan bahkan transaksi narkoba di kawasan tersebut, namun mereka tidak memiliki wewenang atau kuasa untuk mencegah ataupun menghentikan kegiatan tersebut karena khawatir akan keselamatan mereka sendiri. Tindakan utama pemandu wisata bukanlah menghakimi pengedar narkoba tetapi adalah mencegah peredaran narkoba di dunia pariwisata, salah satu nya adalah mengenal tentang jenisajenis narkoba yang perkembangannya selalu berubah-ubah dan modus penjualannya pun bermacam-macam. Oleh karena itu BNN dituntut untuk memberikan materi tentang penggunaan jenis-jenis narkoba yang terbaru atau kekinian pada para masyarakat umum, antara lain para pemandu wisata. 
Dalam bidang pemberdayaan masyarakat, sebenarnya BNN (Badan Narkotika Nasional) telah membentuk satgas anti narkoba di seluruh daerah di Indonesia dengan total 19.854 orang yang terdiri dari pelajar, mahasiswa, swasta, instansi pemerintah, dan masyarakat.

Kantor Wilayah Kementerian Hukum dan HAM DKI Jakarta, Rabu 26 Oktober 2016 juga telah menyelenggarakan kegiatan bhakti sosial di kawasan museum kota tua di Jalan Poskota, Jakarta Barat. Bhakti sosial ini bagian dari bentuk seruan kepada masyarakat untuk berbudaya taat hukum perang terhadap narkoba dan Penelitian ini diadakan untuk menindaklanjuti upaya pemerintah tersebut, dimana pemandu wisata lokal yang bekerja sehari-hari di kawasan tersebut apakah telah mengetahui dan terlibatkah mereka dalam kegiatan tersebut.

\section{Partisipasi Pemandu Wisata Lokal Kota Tua Jakarta dalam Memerangi Narkoba}

Pemandu wisata di Kota Tua sebenarnya telah mengetahui citra Kota Tua yang sedikit banyak bersinggungan dengan narkoba dan prostitusi. Melalui penelitian yang dilakukan, mereka memang belum pernah memasukkan materi tentang narkoba ke dalam materi pemanduan mereka. Setelah mengetahui materi tentang sejarah perkembangan narkoba di Jakarta dalam hal ini khususnya di daerah kota sebagai pusat perdagangan narkoba, maka mereka tertarik untuk memberikan materi narkoba ini ke dalam pemanduan mereka, terutama kepada para pelajar yang berusia rentan terkena dampak narkoba.

Pemandu wisata tersebut memiliki ketertarikan yang sama dalam memberantas narkoba karena merekapun sebenarnya sudah sangat tidak nyaman dengan citra Kota Tua, meskipun sekarang citra tersebut telah membaik. Penggunaan ataupun transaksi narkoba di Kawasan utama Kota Tua Jakarta bisa dikatakan telah hilang, namun kemungkinan bergeser ke bagian lain dari kawasan tersebut tetap masih ada.

Berdasarkan hasil penelitian Nampak jelas bahwa sebagian besar dari mereka telah mengikuti seminar atau sosialisai anti narkoba, namun mereka merasakan kurang efektif karena pesertanya terlalu banyak dan umum. Sosialisasi atau penambahan wawasan seperti ini belum pernah diadakan oleh pihak manapun. Mereka merasa sangat diperhatikan dan terbantu untuk berdiskusi dan bertukar pikiran. Mereka bahkan memberikan masukkan dan saran untuk para pendidik agar dapat memasukkan materi penyalahgunaan narkoba ini dalam pelatihan pemandu pariwisata pada khususnya dan memasukan materi narkoba dalam kegiatan pembelajaran di tingkat SD, SMP, SMU dan Perguruan Tinggi.

Selanjutnya adalah teknik penyampaian materi pemanduan. Ada beberapa hal yang harus disesuaikan dalampenyampaian materi pemanduan antara lain 


\section{Planning For Interpretation}

- menentukan pasar KKTJ (usia,pendidikan dsb)

- $\quad$ Menentukan media interpretasi dan Tujuan interpretasi (termasuk materi pemanduan)

- Melakukan riset

- Mengidentifikasi program pembuatan Media interpretasi

- $\quad$ Menentukan bentuk media interpretasi

- Merencanakan desain media Interpretasi dengan seksama

- Mengimplementasikan perencanaan

- $\quad$ Sosialisasi kepada seluruh petugas dan karyawan KKTJ, JGG dan pemerintah

- $\quad$ Evaluasi dan monitoring

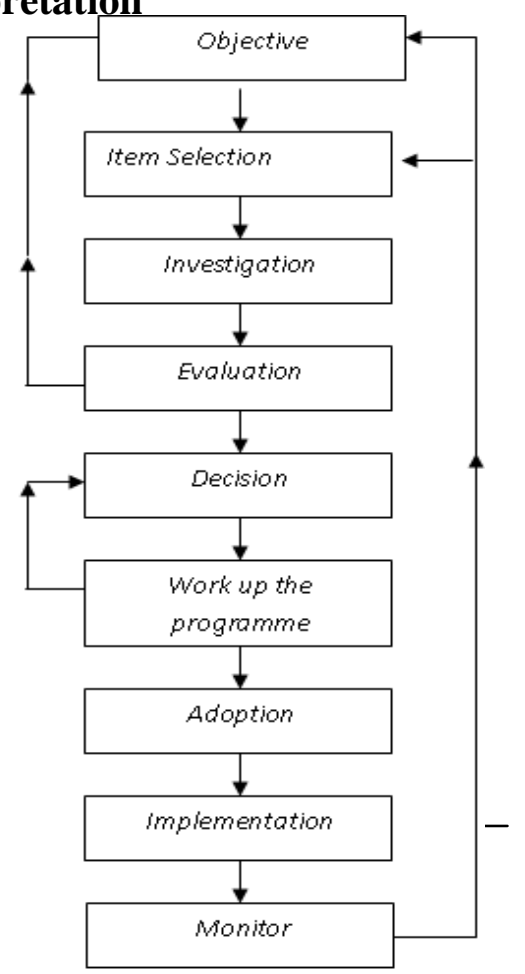

Sumber: Seabroke \& Miles (1993)

Hal diatas menunjukkan bagaimana tahapan sebuah perencanaan materi pemanduan disiapkan. Pada tahap tersebutlah seorang pemandu dapat mulai merencanakan untuk memasukkan materi pencegahan narkoba pada materi pemanduannya. Adapaun implementasi perencanaan materi tersebut adalah sebagai berikut :

a Menyusun Tour/ Pemanduan Keliling

Kegiatan ini dilakukan oleh para guidel interpreter/ pemandu kepada peserta atau wisatawan yang mengunjungi Kawasan Kota Tua Jakarta (KKTJ). Dalam hal ini, pengunjung mengikuti tour dan menerima informasi tentang bangunan yang ada di KKTJ yang bersejarah ataupun sejarah terkait dengan metode berkeliling sesuai dengan rute yang telah ditentukan. Umumnya sebelum dilakukan tour, peserta yang telah terdaftar dibagi kedalam beberapa kelompok dan dalam satu kelompok didampingi oleh $1-2$ orang guidel pemandu. Jumlah peserta dalam satu kelompok biasanya berjumlah $10-15$ orang (jumlah fleksibel berdasarkan banyaknya peserta yang mengikuti program). Pihak Jakarta Good Guide (JGG) dan KKTJ seringkali membatasi jumlah peserta dalam suatu program yang akan dilaksanakan untuk meminimalisasi terjadinya penumpukan peserta pada suatu titik bangunan bersejarah dan menyebabkan terganggunya kegiatan tour antar kelompok.

Dalam tour museum yang merupakan personal interpretation, guide atau pemandu dapat dengan mudah menyesuaikan narasi yang akan disampaikan dengan pengunjung 
yang mengikuti tour, baik secara demografis, geografis dan psikologis secara fleksibel dan akrab, tidak seperti pada non personal interpretation yang hanya mengacu pada penjelasan konkrit saja. Oleh sebab itu tujuan atau objective yang diharapkan, yaitu para wisatawan dapat mengetahui sejarah KKTJ sekaligus memahami bahaya narkoba.

Selanjutnya adalah Item selection atau pemilihan materi dimana pemandu mulai memilih materi pengetahuan narkoba yang sesuai dengan kelompok usia peserta tour. Hal ini untuk mnyesuaikan tingkat pengetahuan, latar belakang pendidikan dan cara penyempaiannya. MaterI dapat diperoleh dengan cara mengadakan investigasi kecilkecilan, studi literature dan kejadian nyata.

Kemudian pemandu dapat melakukan evaluasi dengan saling memberikan materi tersebut ke sesama pemandu atau peserta untuk mendapatkan feed back atau masukkan. Apabila telah mendapatkan masukkan maka perlu dilakukan pengkajian ulang.

Selanjutnya adalah tahap pengambilan keputusan atau decision. Dalam tahap ini pemandu dapat bekerja sama dengan para psikolog, dokter, pekerja sosial atau pemerintah seperti kementerian sosial, kementerian Pariwisata, dan Badan Narkotika Nasional (BNN).

Setelah hal diatas dilakukan, maka pemandu dan JGG dapat mulai bekerjasama dengan pihak pembuatan media cetak atau elektronik agar materi yang diberikan dapat lebih menarik dan visual, misalnya dengan pemutaran film atau lagu dan computer interaktif.

Selanjutnya adalah tahap adopsi dan implementasi, yaitu menggabungkan dan memodifikasi seluruh informasi dan petugas yang terkait. Dalam hal ini perlu diadakan kerjasama dengan seluruh petugas atau pekerja di KKTJ. Para pemandu di JGG telah melarang seluruh anggotanya untuk merokok, dimana merokok merupakan salah satu pintu gerbang menuju narkoba. Hal ini sangat baik dan perlu ditularkan kepada seluruh pekerja di KKTJ minimal pada saat mereka sedang berada di kawasan atau sedang bertugas.

Terakhir adalah tahap pengimplementasian dan monitoring atau evaluasi terhadap apa yang telah dilakukan. Apakah kegiatan ini efektif atau perlu peningkatan. Perlu dilakukan kembali kerjasama dengan pemerintah dan seluruh pihak terkait.

b Pemutaran Film Dokumenter atau Slide

Kegiatan pemutaran film dokumenter atau slide ini perlu dilakukan di dalam ruangan yang dapat disediakan oleh pihak Museum di KKTJ. Ruangan ini harus cukup besar dan dapat menampung sekitar 50 orang. Dilengkapi dengan pemutar film yang cukup baik, televisi dan layar slide di kanan kiri serta kualitas suara yang cukup jelas. Tujuan dari adanya pemutaran film dokumenter atau slide ini adalah agar pengunjung dapat lebih 
memahami sejarah KKTJ. Ruangan ini menjadi sarana untuk penanyangan film-film documenter mengenai kondisi dunia hingga KKTJ menjadi pusat pemerintahan Batavia. Dalam pemutaran film ini, perlu dimasukkan pesan-pesan atau informasi yang berkaitan dengan penyalah gunaan narkoba. Film-film dokumenter juga dapat mengenai kondisi sosial, politik dan budaya serta gaya hidup masyarakat pada masa colonial Belanda, dimana mulai terjadi penjualan narkoba dan prostitusi disekitar kawasan KKTJ tersebut.

c Media Promosi dan Pendistribusian Brosur

Brosur merupakan salah satu teknik interpretasi yang digunakan dalam memberikan informasi secara singkat dan jelas serta informatif tentang suatu objek, tempat, peristiwa ataupun lainnya yang bentuknya bervariasi. Pembagian brosur di KKTJ masih kurang efektif dan bahkan tidak pernah ada kecuali sedang berlangsung sebuah event atau kegiatan. Seharusnya dengan kerjasama yang baik antara pengelola KKTJ, JGG dengan kantor dinas terkait, seperti Dinas Pariwisata, Dinas Pendidikan, Dinas Kebudayaan setempat yang seharusnya dapat berkoordinasi untuk menghasilkan media cetak yang berkualitas dan terdistribusi dengan baik didalam dan luar kota. Bila memungkinkan untuk bekerjasama dengan pihak luar negeri, maka brosur ini juga menjadi salah satu media cetak yang sangat penting perannya hanya saja penggunaan bahasa harus disesuaikan dengan market negara yang akan dituju.

Pada sebuah museum yang baik, seharusnya pihak pengelola dapat mendistribusikan material informasi pokok seperti:

1) Guidebooks (buku panduan KKTJ) : saat ini masih belum ada buku berisikan berbagai macam informasi dan foto-foto mengenai KKTJ.

2) Souveneers : saat ini telah ada beberapa jenis souvenir seperti mug, tas, kaos dsb, namun konter penjual souvenir ini sangat tersembunyi letaknya (dibagian belakang museum) dan kurang menarik

3) Visitor map (peta wisata dan tour KKTJ) : saat ini masih belum ada peta wisata KKTJ yang dapat dimiliki oleh pengunjung

4) Pesan atau cerita sejarah tentang berkembangnya narkoba di jaman penjajahan Belanda hingga sekarang. Hal yang sebenarnya bukan hal yang tabu untuk ditutupi dari kondisi yang terjadi. KKTJ sebelumnya dan bahkan hingga saat ini masih sering terjadi sebagai tempat transaksi dan konsumsi narkoba. Perlu disampaikan kepada pengunjung bahwa upaya pemerintah dalam memerangi narkoba telah sampai suatu titik tertentu dan terus berlanjut, sehingga masyarakat dapat informasi yang jelas mengenai hal ini dan tidak lagi menjadi khawatir akan hal yang berkaitan dengan 
narkoba tersebut selama berada di KKTJ. Hal ini sangat diperlukan karena bagaimanapun stigma dan persepsi masyarakat mengenainarkoba dan KKTJ masih terus ada.

\section{d Petugas KKTJ}

Petugas KKTJ, dalam hal ini adalah petugas yang "Guest Contact" masih belum memiliki jiwa "hospitality" yang kental, nampak bahwa petugas yang bertugas di sudut di TIC )Tourism Information Center) yang kurang memahami KKTJ ini secara keseluruhan. Selain itu, mereka tidak menggunakan atribut guest service officer yang sesuai seperti seragam dan nama dada. Hal ini mencerminkan ketidak profesionalan dalam memberikan pelayanan kepada wisatawan. Selain itu, para pemandu juga tidak menggunakan seragam yang khas meskipun berpenampilannya sudah cukup rapi. Seharusnya, untuk meningkatkan kualitas pengalaman pengunjung, para pegawai KKTJ dapat mengenakan seragam yang sesuai dengan tema museum tersebut, misalnya pakaian yang modelnya disesuaikan dengan masa pada saat Kolonial Belanda.

Pemandu atau guide merupakan petugas yang paling penting yang dimiliki oleh sebuah Kawasan bersejarah. Pada kawasan ini, pemandu memiliki pengetahuan yang cukup detil dan dapat menyampaikan dengan baik dan jelas kepada pengunjung. Mereka juga dapat dengan seksama menjelaskan dan menggambarkan momen-momen penting yang terjadi di KKTJ. Hal ini merupakan daya tarik luar biasa bagi pengunjung. Pemandupemandu yang berada di bawah naungan JGG ini merupakan pemandu yang sudah cukup terlatih, dapat menguasai berbagai bahasa dan telah mendapatkan sertifikasi dan pelatihan dari Dinas Pariwisata Daerah dan telah tergabung dalam Himpunan Pramuwisata Indonesia atau HPI.

e Partisipasi Pelarangan membawa Miras dan Narkoba oleh Pemandu Wisata.

Keterlibatan secara personil dari para pemandu umtuk menerapkan peraturan bagi para turis asing maupun lokal dengan cara melakukan pemeriksaan barang bawaan ketika mau masuk kedalam bis wisata maupun ketika akan masuk kedalam bis setelah dari lokasi wisata, sangat penting sekali, jika memungkinkan menggunakan alat detector yang canggih, sehingga program Indonesia darurat narkoba bisa diatasi sedini mungkin lewat berbagai sektor khususnya sektor pariwisata,

\section{Penutup}

Berdasarkan penelitian terjadinya penyalahgunaan narkoba yang dilakukan di Kota Tua Jakarta ini, maka dapat disimpulkan bahwa hal ini terjadi akibat: adanya faktor 
individu, lingkungan dan ketersediaan narkoba itu sendiri, sehingga perlunya pemerintah dan masyarakat menciptakan lingkungan di Kota Tua yang aman dan bebas penyalahgunaan narkoba. Dalam hal ini pemerintah dapat bekerja sama dengan para pemandu wisata yang bekerja di Kawasan Kota Tua tersebut.

Penyalahgunaan narkoba juga terjadi akibat adanya pengaruh luar yang datanag ke kawasan tersebut dengan mambawa narkoba seperti para wisatawan atau masyarakat luar Kota Tua Jakarta, untuk itu hendaknya para pemandu wisata memasukkan materi narkoba ini kedalam materi pemanduan ketiak mereka memandu. Dalam hal ini para pemandu, khususnya yang berada di bawah manajemen Jakarta Good Guide telah setuju untuk melakukan hal ini.

Berdasarkan hasil temuan, disusun saran sebagai berikut, 1) Pemandu wisata membuat materi pemanduan yang didalamnya memuat materi mengenai penyalahgunaan narkoba dikaitkan dengan sejarah Kota Tua sebelumnya; 2) Pemandu wisata berama-sama dengan masyarakat setempat mengadakan pengawasan dan monitoring di kawasan Kota Tua Jakarta agar terbebas dari penyalahgunaan narkoba, 3) Pemandu wisata bersama-sama dengan pemerintah dan BNN agar secara berkala melakukan sosialisasi dan bahkan tes urin di kawasan Kota Tua Jakarta; 4) Pemerintah, pemandu wisata dan wisatawan bersamasama menciptakan suasana aman dan menyenangkan di Kota Tua agar menjadi kawasan yang harmonis dan aman tanpa khawatir akan adanya bahaya narkoba dan ancaman dari orang-orang yang terkena narkoba, seperti penularan penyakit, prostitusi, premanisme dan sebaganya. 5) pemandu wisata melakukan pemeriksaan terhadap turis asing dan lokal untuk tidak membawa miras dan narkoba selama berada dalam bis dan lokasi wisata oleh pemandu wisata belum dilakukan secara intensif. 6) Pemandu wisata mendorong pemerintah untuk memberlakukan hukuman mati atau hukuman paling berat terhadap pengedar, penyelundup dan produden narkoba secara konsisten

\section{E. Daftar Pustaka}

Alifia, U, 2008. Apa Itu Narkotika dan Napza. PT Bengawan Ilmu, Semarang

A, Yoeti, Oka. Edisi Revisi 2008, Pengantar Ilmu Pariwisata, Penerbit Angkasa, Bandung.

Buku Advokasi Pencegahan Penyalahgunaan Narkoba, BNN : 2009

Buku panduan BNN, Pelajar dan Bahaya Narkotika, Deputi Bidang Pencegahan Direktorat Diserminasi Informasi, Jakarta 2010

Cooper, et al., 2005. Tourism Principles and Practice. Essex: Pearson Education 
Conyers, Perencanaan Sosial di Dunia Ketiga, Suatu Pengantar, Yogyakarta : Gajah Mada University Press, 1994

Millar, S (1989). Heritage Management for Heritage Tourism. Tourism Management, 10 (1), p9-14

Moleong, Lexy J. 2012. Metodologi Penelitian Kualitatif. Bandung : Remaja Rosdakarya

Partodiharjo, S, 2008. Kenali Narkoba dan Musuhi Penyalahgunaannya.Erlangga. Surabaya

Spillane, J.J. 1993, Ekonomi Pariwisata Sejarah dan Prospeknya, Kanisiun, Yogyakarta

Slamet, 1994, Pembangunan Masyarakat Berwawasan Partisipasi, Surakarta : UNS Press

Sugiyono.2012. Memahami Penelilitian Kualitatif. Bandung : AlfaBeta

Sastropoetro, 1988. Partisipasi, Komunikasi, Persuasi dan Disiplin Dalam Pembangunan Nasional, Bandung : Alumni, h 13

Seabroke, W and Miles, C.W.N (1993). Recreation Land Management. London : E \& FN SPON

Tilden, F (1078). Interpreting Our Heritage. North Carolina : The University of North Carolina Press

Undang-Undang Kepariwisataan No. 10 Tahun 2009

Utami, Heryanti. Thesis: Optimalisasi Pengembangan Kawasan Kota Tua Jakarta sebagai Urban Heritage Tourism berbasis Experiential Marketing. Sekolah Tinggi Pariwisata Bandung. Bandung : 2010

Vanhove N. 2005. The Economics of Tourism Destinations. Elsevier. Burlington

Veverca, JA (1998). Interpretive Master Planning : The Essential Planning Guide for Interpretive. Tustin : Acorn Naturalist

\section{Website}

http://dedihumas.bnn.go.id/read/section/artikel/2014/03/10/929/pengertian-narkoba, diakses pada tanggal 10 Maret 2017, pukul $09.00 \mathrm{wib}$

http://news.liputan6.com/read/761474/razia-di-kawasan-kota-tua-14-pengunjung-positifnarkoba diakses pada tanggal 10 Maret 2017, pukul 09.00 wi

http://hariannetral.com/2014/10/pengertian-narkoba-bahaya-dan-dampak-narkoba.html diakses pada tanggal 10 Maret 2017, pukul 09.00 wib

http://kbbi.web.id/partisipasi diakses pada tanggal 27 Februari 2017, pukul 06.53 wib https://agus34drajat.files.wordpress.com/2010/10/buku-pedoman-praktis-mengenaipenyalahgunaan-napza-bagi-petugas.pdf. Diakses pada tanggal 31 Juli 2017 pukul 15.30 wib 
http://news.liputan6.com/read/2445712/bnn-musnahkan-120-kg-sabu-di-kota-tua. Diakses pada tanggal 31 Juli 2017 pukul 15.30 wib

http://megapolitan.kompas.com/read/2016/06/23/11491421/presiden.jokowi.akan.hadiri.pe ringatan.hari.anti-narkotika.di.kota.tua. Diakses pada tanggal 31 Juli 2017 pukul 15.30 wib

http://hukum.rmol.co/read/2016/06/26/251298/Capaian-Komjen-Buwas-Di-Hari-AntiNarkoba-2016- Diakses pada tanggal 31 Juli 2017 pukul 15.30 wib

http://dedihumas.bnn.go.id/read/section/artikel/2014/03/10/929/pengertian-narkoba.

Diakses pada tanggal 31 Juli 2017 pukul 15.30 wib

http://www.pikiran-rakyat.com/bandung-raya/2011/07/07/151095/sektor-kepariwisataanrentan-terhadap-fenomena-narkoba) diakses pada tanggal 10 Maret 2017, pukul $09.00 \mathrm{wib}$

(WFTGA Scotland 2003). diakses pada tanggal 10 Maret 2017, pukul 09.00 wib

https://hpibandungwestjava.wordpress.com/tag/guide-muda-n-madya/ diakses pada tanggal 25 Desember pukul 13.00 